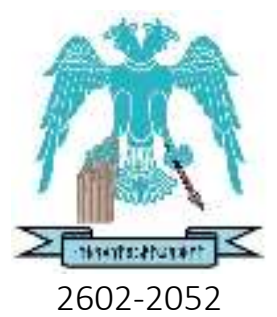

JOURNAL OF ENERGY SYSTEMS

VOLUME 2, ISSUE 4

DOI: $10.30521 /$ jes. 455325

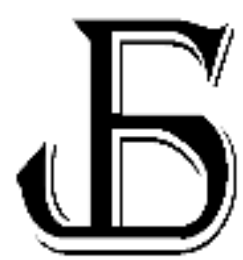

Research Article

\title{
Potential of biogas energy from animal waste in the Mediterranean Region of Turkey
}

\author{
Zuhal Akyürek \\ Mehmet Akif Ersoy University, Faculty of Engineering and Architecture, Burdur, Turkey, \\ drzuhalakyurek@gmail.com \\ ORCID: 0000-0003-3102-4278
}

Arrived: 27.08.2018 Accepted: 10.11.2018 Published: 31.12.2018

\begin{abstract}
Continuous growth in global energy demand, depletion of fossil resources and climate change concerns associated with fossil fuel combustion have increased the motivation on utilization of renewable energy sources. Utilization of renewable sources is vital in Turkey as the country highly depends on imported energy. Biogas is a renewable energy resource produced from decomposing organic waste under anaerobic conditions. Production of biogas from organic wastes such as animal manure is advantageous to contribute renewable energy production and waste management strategies for health and environmental protection. In this study, the animal manure based biogas energy potential of the Mediterranean Region of Turkey is determined. The region is composed of eight provinces including Antalya, Burdur, Isparta, Mersin, Adana, Hatay, Osmaniye and Kahramanmaraş. The results revealed that Mediterranean Region has $183 \mathrm{Mm}^{3}$ annual biogas potential corresponding to $0.08 \mathrm{MTOE} / \mathrm{year}$ energy generation capacity. Codigestion of agricultural residues can contribute to about $0.208 \mathrm{MTOE} /$ year energy generation. It is determined that biogas production can contribute reduction of carbon footprint by 1.7 million tons of annual $\mathrm{CO}_{2}$ emissions. Mersin Province has shown the highest biogas potential in the region.
\end{abstract}

Keywords: Biogas, Animal manure, Waste management, Renewable energy, Turkey

Akyürek, Z, Potential of biogas energy from animal waste in the Mediterranean

Cite this paper as: $\quad$ Region of Turkey. Journal of Energy Systems 2018; 2(4): 160-167, DOI: 10.30521/jes. 455325

(C) 2018 Published by peer-reviewed open access scientific journal, JES at DergiPark (www.dergipark.gov.tr/jes) 


\section{INTRODUCTION}

The global demand for energy has been steadily increasing in the last decades due to rapid growth in population, industrialization and improvement of technology. Energy security, economic growth, environmental protection are the main drivers of national energy policies in any country of the world today to achieve sustainable development. Anthropogenic emissions result in environmental pollution leading to climate change. To reduce the adverse effects of fossil fuel combustion, integration of renewable energy systems has been increasing in both number and capacity. Biomass is one of the promising alternatives of renewable energy to meet future energy demand and to reduce greenhouse gas emissions [1-6]. According to the International Energy Agency's (IEA) World Energy Outlook 2015 (WEO 2015) the share of biomass accounts for $14 \%$ in the world global energy mix and expected to rise in foreseeable future.

Wastes from agriculture, livestock, urban and industry have adverse environmental and health effects. These wastes become the main emitters of non-carbon dioxide greenhouse gases (methane and nitrous oxide) if they are not carefully disposed [7,8]. Anaerobic digestion is one of the favorable biomass conversion technologies to convert organic wastes into renewable energy and to effectively mitigate the greenhouse gas emissions. Application of anaerobic digestion for biogas production is a widespread bioenergy production route due to its robust design configurations serving for multiple purposes $[9,10]$. Biogas produced from anaerobic digestion process is mainly composed of methane (35-75\%), carbon dioxide (25-65\%), hydrogen (1-5\%). Bio-methane in biogas is a valuable energy carrier similar to natural gas $[11,12]$. Hence, biogas could be a potential energy source for heat and electricity production for the foreseeable future. Moreover, during anaerobic digestion of waste materials organic fertilizer with high quality is produced as biogas plant residue.

Animal manure is one of the favorable feedstock for biogas production. The conversion of animal waste to biogas through anaerobic digestion (AD) processes is advantageous owing to prevention of waste problems, unpleasant odors and microbial pathogens in livestock farms, production of renewable energy, and production of organic fertilizers compared to conventional manure management solutions. When manure is co-digested with the agro-residues, the production yield can further be promoted [13-15].

Biogas is predicted to have an important role for achieving energy targets of European Union due to its flexibility and storability of bio-methane as an energy carrier and having a wide range of applications such as heating, transportation and electricity production. European Union (EU) has set out policy targets for climate and energy as 40\% reduction in greenhouse gas emissions in compared to 1990 levels, $27 \%$ share of renewable energy in installed capacity and at least $27 \%$ energy savings compared with the business-as-usual scenario [16]. The feedstock of biogas sector should be carefully considered in order to ensure sustainable biogas production and reduce its potential impacts on the environment, nature and climate, and current food and biomaterial production chains [17].

According to Intended Nationally Determined Contribution covering the period 2012-2030 [18], Turkey aims to contribute to the collective efforts to combat climate change in line with its national circumstances and capabilities. The greenhouse gas inventory of the year 2012 revealed that the total emissions in 2012 expressed in CO2 equivalent were 440 million tons in Turkey. The energy sector had the largest share with $70.2 \%$ followed by Industrial processes with $14.3 \%$, waste sector with $8.2 \%$ and agricultural sector with $7.3 \%$. Reduction in total greenhouse gas emissions set out to reduce up to $21 \%$ by 2030 with the improvements in energy, industrial processes and products use, agriculture, land use land-use change and forestry, and the waste utilization sectors. Turkey has also announced a reduction in greenhouse gas emissions from 1175 to 929 million ton $\mathrm{CO}_{2}$ equal in 2030 in The Tenth Development Plan (2014-2018) by pointing out the prior actions to address the issues of climate change and environmental pollution, with regard to solid waste disposal and recycling [19]. In order to fulfill these 
obligations and prevent the adverse environmental impact of fossil fuels on climate change, Turkey needs to utilize indigenous sources and produce renewable energy.

Agricultural activities and livestock farming has high economic value in Turkey. The abundancy of agricultural residues and livestock manure signify their potential for biogas production. The total livestock biogas potential of Turkey is originated from $68 \%$ cattle, $5 \%$ small ruminant and $27 \%$ poultry [20]. In this study livestock manure based biogas potential is determined for Mediterranean Region of Turkey which occupies the entire southern coast of Turkey. The climate of the region is characterized by rainy winters and hot, dry summers at the coast and cold, snowy winters and hot, dry summers in the interior. The agricultural activities especially greenhouse sector and livestock farming have great contribution to the economy of the region due to fertile lands and warm climate. Although there are a few studies for estimating the biogas potential of different waste materials in Turkey in the last decade [21-23], there are no studies available for biogas status of Mediterranean Region. Therefore, this study attempts to identify the biogas potential of cities in the Mediterranean Region of Turkey considering livestock manure capacity using the most recent data to assess the utilization of these waste in terms of energy generation, electricity generation capacity, organic fertilizer production, greenhouse gas emission reduction and health benefits from biogas operations. In addition, the total biogas potential of the region from co-digestion of animal waste and agro residues has also been evaluated.

\section{MATERIALS AND METHODS}

In this study, the animal manure based biogas production potential of the eight cities (Antalya, Burdur, Isparta, Mersin, Adana, Hatay, Osmaniye and Kahramanmaraş) located in Mediterranean Region of Turkey and the total theoretical biogas potential of the region based on animal manure, MSW and forestry residues have determined. Energy and electricity equivalence of the biogas potential, and the amount of organic fertilizer that could be produced from the residue of the biogas production plant production have also been determined. The total number of cattle, small ruminant (sheep and goat) and poultry are provided from General Directorate of Renewable Energy, Turkey [24]. The distribution of number of animals is presented in Table 1. The number of animals were used to calculate the amount of manure potential for the provinces in the region. Several factors influence the amount of daily animal manure and cumulative biogas potential in the livestock operations. Type of the animal, feeding regime, body weight, total solids ratio (TS), volatile solids ratio (VTS), the availability ratio of waste and biogas yield have high impact on the waste potential from animals. Availability of waste must be taken into account in determining the biogas production potential from animal waste. While availability of the poultry manure is very high, cattle manure can be collected in less amount and for small ruminant, the availability of the manure is much lower due to the restricted stay of the animals in the shelter. In Table 2 , typical waste characteristics of the livestock are presented.

Table 1. Livestock and poultry population in Mediterranean Region of Turkey in year 2018.

\begin{tabular}{llll}
\hline Province & Cattle & Small Ruminant & Poultry \\
\hline Adana & 216,358 & 638,280 & $4,221,371$ \\
Antalya & 160,946 & 1141,951 & 511,860 \\
Burdur & 233,677 & 393,778 & 171,558 \\
Hatay & 124,504 & 332,005 & $1,022,445$ \\
Isparta & 147,788 & 466,436 & 421,582 \\
Mersin & 101,833 & 1295,313 & $17,939,270$ \\
Osmaniye & 65,371 & 190,307 & 600,177 \\
Kahramanmaraş & 178,194 & 659,267 & $1,135,957$ \\
\hline
\end{tabular}


Table 2. Waste Characteristics by type of animals [22, 23]

\begin{tabular}{llllll}
\hline Animal Type & Manure (kg/day) & TS \% & VTS \% & Availability \% & Biogas Yield 1/kg VTS \\
\hline Cattle & $10-25$ & $10-20$ & $75-85$ & $50-65$ & $100-300$ \\
Small Ruminant & $2-4$ & $25-30$ & $70-80$ & $5-13$ & $10-50$ \\
Poultry & $0.05-0.1$ & $40-60$ & $60-80$ & $95-99$ & $300-500$ \\
\hline
\end{tabular}

Theoretical biogas generated from the manure is calculated as follows:

$$
T B P=M \times T S \times V T S \times A C \times E B_{V T S}
$$

where TPB denotes the theoretical potential of biogas ( $\mathrm{m}^{3} / \mathrm{year}$ ), $\mathrm{M}$ is the total amount of the manure produced for each city (kg/year) TS represents the ratio of the total solids of the animal manure, VTS represents the ratio of the volatiles in total solids of the animal manure, AC denotes the availability \% and $\mathrm{EB}_{\mathrm{VTS}}$ is the quantity of estimated biogas produced per $\mathrm{kg}$ of the volatile total solids ( $1 / \mathrm{kg}$ VTS).

The amount of energy produced from bio-methane $(\mathrm{kWh} / \mathrm{year})$ is calculated based on Equation 2;

$$
E_{M}=T B P * M_{p} * E_{C H_{4}}
$$

$\mathrm{M}_{\mathrm{P}}$ represents the methane production ratio of biogas $\%, \mathrm{E}_{\mathrm{CH} 4}$ is the energy content of methane, 36 $\mathrm{MJ} / \mathrm{m}^{3} \mathrm{CH}_{4}[25]$

Electricity generation from bio-methane is calculated from Equation 3;

$$
E_{M e}=E_{M} * e
$$

$e$ denotes electricity conversion of bio-methane energy depending on the power generation plant $(30-40 \%)[26]$.

The fermentation process reduces the organic dry matter content of original material to 24-80\% [27]. Co-digestion of animal manure with agricultural residues can utilize the nutrients and bacterial diversities in various wastes to optimize the digestion process and results in higher methane yield compared with anaerobic digestion of cattle manure alone [28]. Agro-residues in Mediterranean Region accounts for approximately 13.6 Mtons/year [24]. In order to obtain the biogas potential of the Region agricultural residues have also considered together with animal manure potential. The biogas yield of the agricultural residues changes within a wide range from $1231 / \mathrm{kg}$ VTS (banana stalk and leaves) to 344 1/kg VTS (cotton residue) [29, 30].

\section{RESULTS and DISCUSSION}

The potential of biogas from livestock manure was calculated for all provinces of Mediterranean Region of Turkey. The amount of wet waste production by cattle, small ruminant and poultry in the region according to the data recorded in 2018 is shown in Figure 1. As can be seen from the figure, the maximum amount of manure was produced in Mersin province. It is obvious that poultry made 
significant contribution to production of manure in Mersin. It could be attributed to the augmentation of poultry industry in Mersin. Among the farm animals, cattle have shown to have the highest manure production with 6.3 Mton/year in the region. Among the farm animals, cattle manure exhibited higher quantity of biogas production potential compared to that from small ruminant. Estimated biogas potential from animal manure is shown in Figure 2. Animal manure potentially obtained from the farm animals in the Region have about 186 Million $\mathrm{m}^{3}$ of annual biogas production capacity. This indicates that animal manure could be efficiently managed for further processing in the biogas plants for renewable energy production and environmental protection.

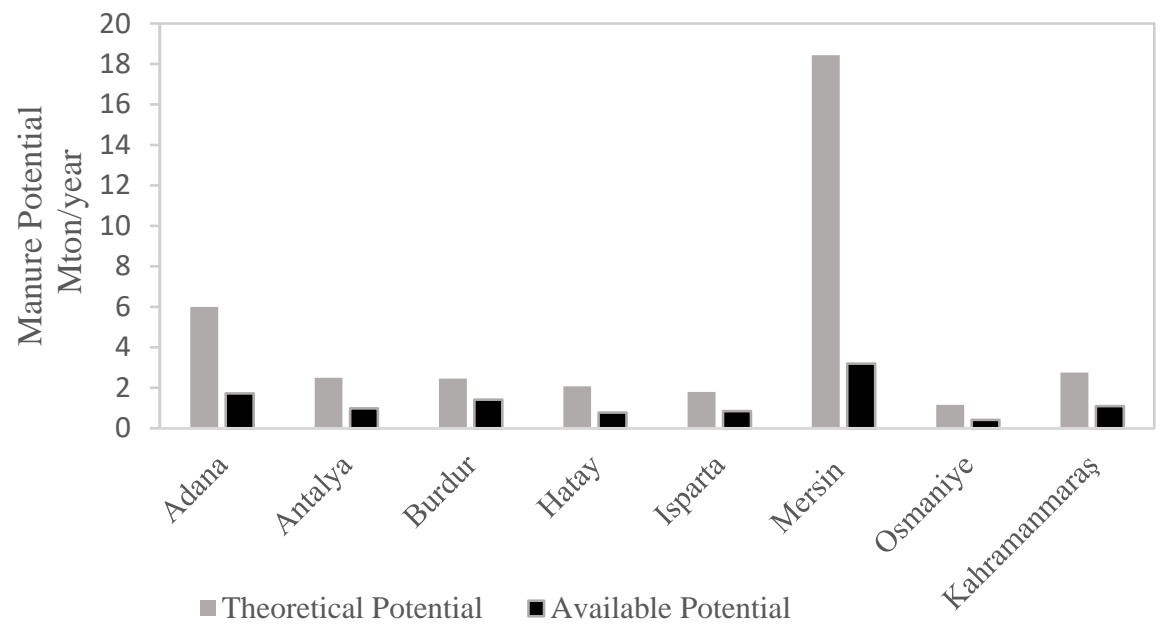

Figure 1. Theoretical and available animal manure potential in Mediterranean Region of Turkey.

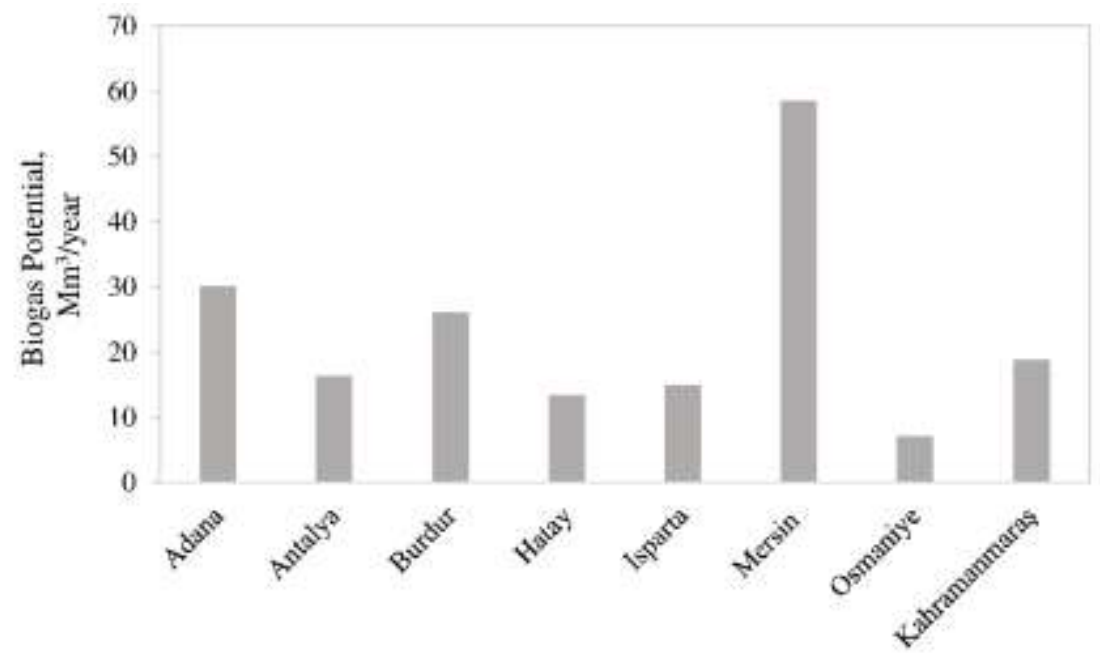

Figure 2. Biogas Potential of the Provinces in Mediterranean Region of Turkey

Energy potential of the livestock manure in the Region is shown in Figure 3. The figure reveals that Mersin Province has highest energy generating capacity followed by Adana and Burdur. Total energy equivalence of the biogas energy potential from animal manure has estimated as $0.08 \mathrm{MTOE} / \mathrm{year}$. It is known that co-digestion of livestock manure with agricultural crop residues can enhance methane yield during fermentation. Cow manure co-digested with $30 \%$ of agricultural crops resulted in $16 \%$ increase in methane gas production [31]. In Mediterranean Region co-utilization of agro-residues has estimated to increase the energy generation potential at about $0.208 \mathrm{MTOE} / \mathrm{year}$. 
The results of this study revealed that significant part of the Region electricity generation could be met by biogas energy. The use of manure-derived biogas in the region corresponds to approximately 91.7 $\mathrm{Mm}^{3}$ of natural gas consumption. Hence, biogas generation from animal waste can have positive impact to Turkish Economy in terms of reducing the amount of imported natural gas. The electricity generation capacity from animal manure in the Region has estimated as 334 GWe/year. The distribution of the electricity generation potential has demonstrated in Figure 4.

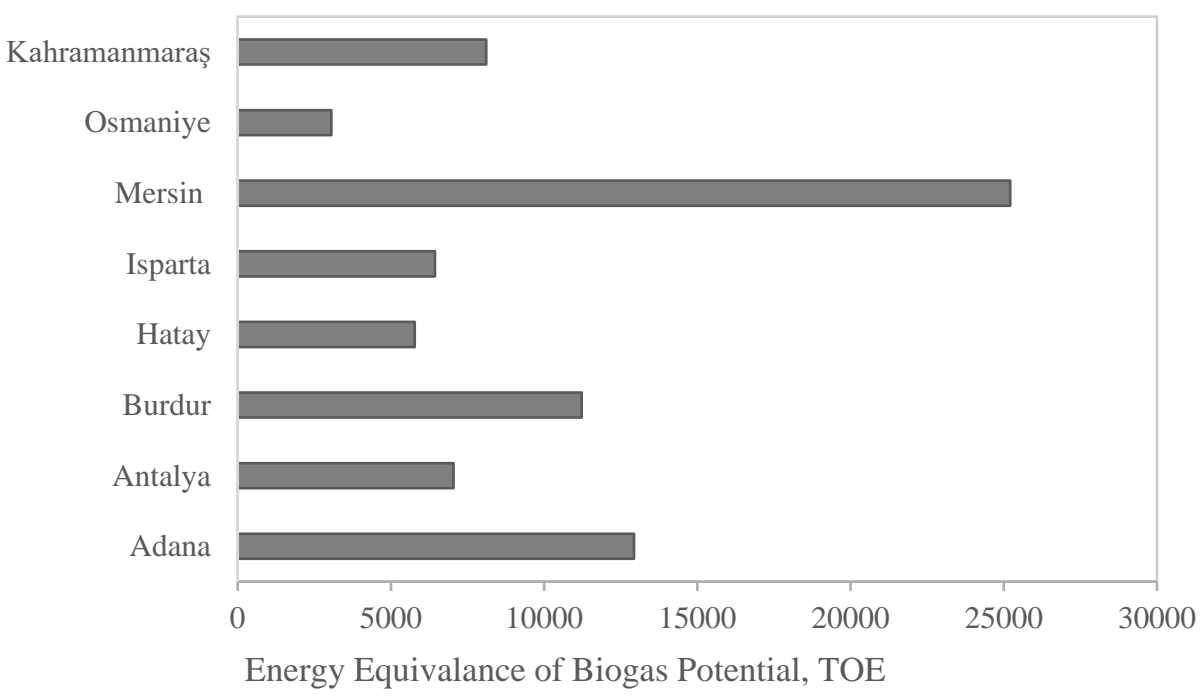

Figure 3. Energy equivalence of biogas potential from animal manure in Mediterranean Region of Turkey.

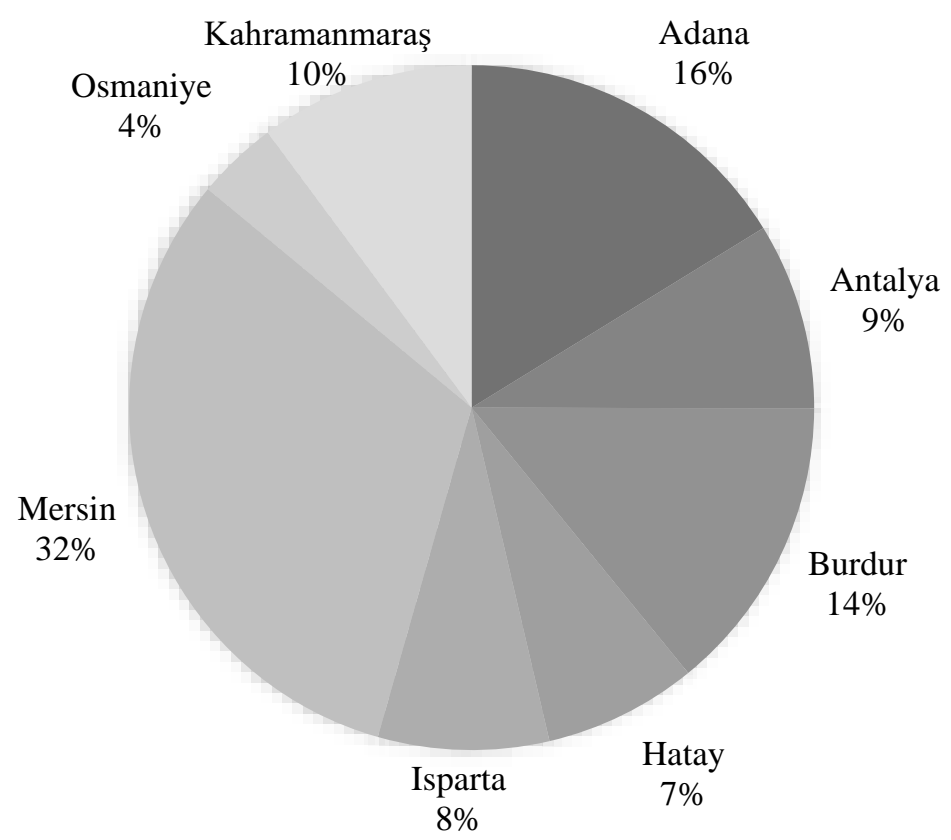

Figure 4. Share of the provinces in electricity generation potential from animal manure in Mediterranean Region of Turkey. 


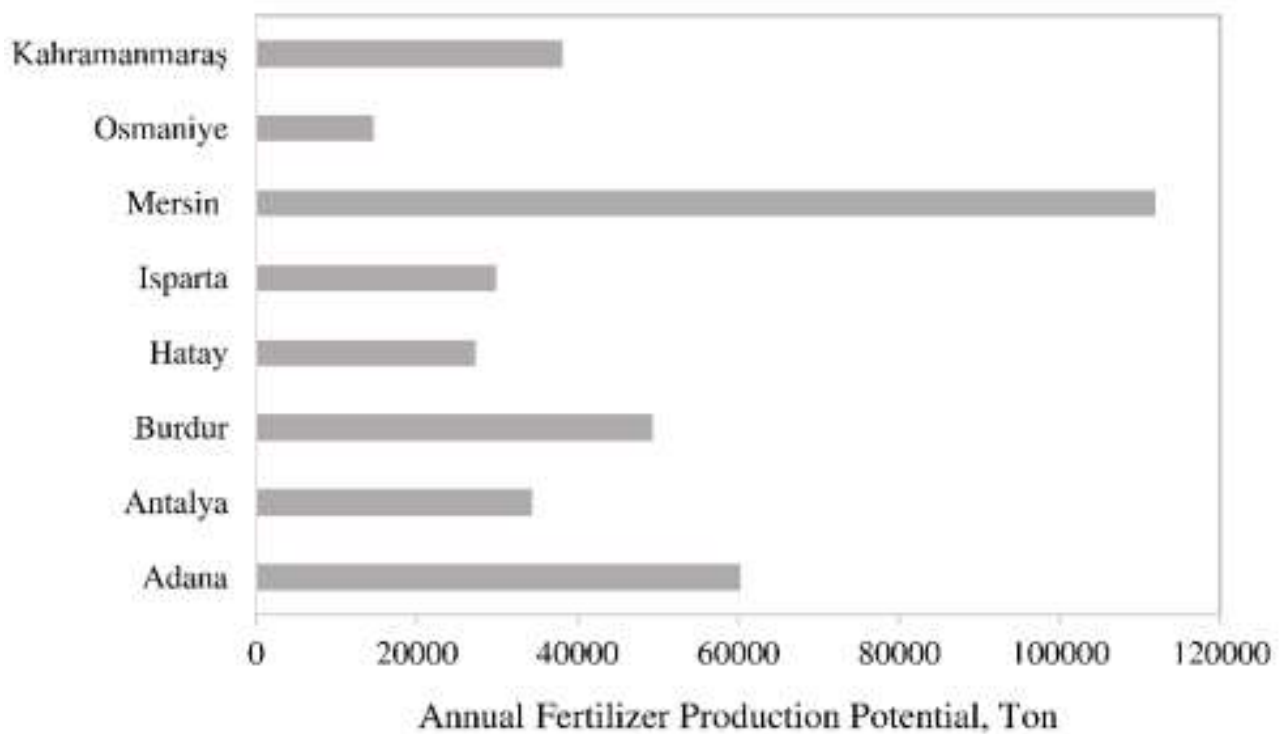

Figure 5: The amount of organic fertilizer production potential

The agricultural sector and livestock farming sector is a major contributor to Turkish economy. Livestock manure is one of the major contributors to environmental problems due to methane generated from untreated waste. In addition, the discharge of the untreated livestock waste contaminates the environment with high levels of pathogens, endangering the human and animal health. To meet the demand for energy and a healthy environment it is necessary to progressively adopt the environmentally friendly waste conversion practices. By the utilization of animal manure for biogas production 1.7 Mton/year $\mathrm{CO}_{2}$ emission can be achieved in the region.

Anaerobic digestion of animal waste converts a major part of organic nitrogen to ammonia, which is then directly available to plants as a nitrogen source [32]. In addition to nitrogen, the digested residue as a fertilizer could be used as phosphorus source. Therefore, the residual of the biogas production plant offers an attractive alternative to commonly used mineral fertilizers. The amount of organic fertilizer production from anaerobic digestion of animal manure in Mediterranean Region is shown in Figure 5. The region has about 0.3 Mtons of annual organic fertilizer production potential.

\section{CONCLUSION}

Energy resource concerns and the need for mitigation of environmental impacts associated with energy generation from fossil fuels have increased the deployment of renewable energy. Biogas production from animal waste offers waste management solutions and sustainability of energy sources. In this study the livestock manure potential of Mediterranean Region of Turkey was examined. Cattle manure, small ruminants and poultry manure potentials are assessed for energy and organic fertilizer production. Contribution of agricultural residues to biogas potential in the region has also considered. The estimated biogas potential from animal manure in the region corresponds to annual 0.08 MTOE energy generation. Co-digestion of agricultural residues can contribute energy generation of about 0.208 MTOE. Mersin Province has shown the highest biogas potential in the region. Biogas production from livestock manure in Mediterranean Region can reduce annual $\mathrm{CO}_{2}$ emission by $1.7 \mathrm{Mtons}$ and contributes to global climate combat. In conclusion, biogas produced from livestock manure could be one of the significant sources of renewable energy production in Turkey. 


\section{REFERENCES}

[1] Mao, G., Huang, N., Wang, H. Research on biomass energy and environment from the past to the future: A bibliometric analysis. Science of The Total Environment 2018;635:1081-1090. DOI: https://doi.org/10.1016/j.scitotenv.2018.04.173

[2] Toklu, E., Biomass energy potential and utilization in Turkey. Renewable Energy 2017; 107: 235-244. DOI: https://doi.org/10.1016/j.renene.2017.02.008

[3] Bilgili, F., Bulut, Ü., Kuşkaya, S., Can biomass energy be an efficient policy tool for sustainable development? Renewable and Sustainable Energy Reviews 2017; 71: 830-845. DOI: https://doi.org/10.1016/j.rser.2016.12.109

[4] Bhattacharya, S.C., Salam, P.A., Pham, H.L., Ravindranath, N.H.,Sustainable biomass production for energy in selected Asian countries, Biomass and Bioenergy 2003; 25: 471-482. DOI: https://doi.org/10.1016/S09619534(03) 00085-0.

[5] Hughes, E., Biomass cofiring: economics, policy and opportunities. Biomass and Bioenergy 2000; 19: 457465. DOI: https://doi.org/10.1016/S0961-9534(00)00057-X

[6] Mao, C., Yongzhong, F., Xiaojiao, W., Guangxin, R., Review on research achievements of biogas from anaerobic digestion. Renewable and Sustainable Energy Reviews 2015; 45: 540-555. DOI: https://doi.org/10.1016/j.rser.2015.02.032

[7] Scheftelowitz, M., Thrän, D. Unlocking the energy potential of manure: an assessment of the biogas production potential at the farm level in Germany, Agriculture 2016; 6 (20); 2-13. DOI:10.3390/agriculture6020020

[8] Monteny, G.J., Bannink, A., Chadwick, D. Greenhouse Gas Abatement Strategies for Animal Husbandry. Agriculture,I Ecosystem \& Environment 2006, 112: 163-170. https://doi.org/10.1016/j.agee.2005.08.015

[9] Holm-Nielsen, J.B., Al Seadi, T., Oleskowicz-Popiel, P. The future of anaerobic digestion and biogas utilization. Bioresource Technology 2009, 100: 5478-5484. https://doi.org/10.1016/j.biortech.2008.12.046

[10] Ulukardeşler A.H., Atalay, F.S. Kinetic studies of biogas generation using chicken manure as feedstock, Journal of Polytechnic 2017: 1-7. DOI: 10.2339/politeknik.389622

[11] Yentekakis, I.V. and Grammatiki, G., Biogas Management: Advanced Utilization for Production of Renewable Energy and Added-value Chemical, Frontiers in Environmental Science 2017; 5, 1-18. DOI: https://doi.org/10.3389/fenvs.2017.00007

[12] Lyytimäki, J., Renewable energy in the news: Environmental, economic, policy and technology discussion of biogas. Sustainable Production and Consumption 2018; 15: 65-73.

[13] Samira, Z., Evaluation of biogas potential from livestock manures and rural wastes using GIS in Iran. Renewable Energy 2018; 118: 351-356 DOI: https://doi.org/10.1016/j.renene.2017.11.026

[14] Batzias, F.A., Sidiras, D.K., Spyrou E.K., Evaluating livestock manures for biogas production: a GIS based method. Renewable Energy 2005; 30: 1161-1176. DOI: https://doi.org/10.1016/j.renene.2004.10.001

[15] Hijazi, O., Munro, S., Zerhusen, B., Effenberger, M., Review of life cycle assessment for biogas production in Europe. Renewable and Sustainable Energy Reviews 2016; 54: 1291-1300

[16] European Commission: 2030 Energy Strategy. https://ec.europa.eu/energy/en/topics/energy-strategy-andenergy-union/2030-energy-strategy (Accessed August 27, 2018)

[17] Meyer, A.K.P, Ehimen, E.A., Holm-Nielsen, J.B., Future European biogas: Animal manure, straw and grass potentials for a sustainable European biogas production. Biomass and Bioenergy 2018; 111: 154-164. DOI: https://doi.org/10.1016/j.biombioe.2017.05.013

[18]Republic of Turkey Intended Nationally Determined Contribution http://www4.unfccc.int/submissions/INDC/Published\%20Documents/Turkey/1/The_INDC_of_TURKEY_v .15.19.30.pdf. (Accessed August 27, 2018).

[19] The Tenth Development Plan 2014-2018, http://www.mod.gov.tr/Lists/RecentPublications/Attachments/75/The\%20Tenth\%20Development\%20Plan \%20(2014-2018).pdf. (Accessed August 27, 2018).

[20] Avcioglu, O., Turker, U., Status and potential of biogas energy from animal wastes in Turkey, Renewable and Sustainable Energy Reviews 2012; 16: 1557-1561. DOI: https://doi.org/10.1016/j.rser.2011.11.006

[21] Kaygusuz, K., Renewable and sustainable energy use in Turkey: a review. Renewable and Sustainable Energy Reviews 2002; 6: 339-366. https://doi.org/10.1016/S1364-0321(01)00007-7

[22] Ozyurt, O. Energy issues and renewables for sustainable development in Turkey. Renewable and Sustainable Energy Reviews 2010; 14: 2976-2985. https://doi.org/10.1016/j.rser.2010.08.002

[23] Kara, B., Emir, Z., Seker, T. Bahadir, A., Kaygusuz, K. Current state and future prospects of biomass energy in Turkey. Journal of Engineering Research and Applied Science 2017; 6: 522-529. ISSN 2147-3471 
[24] General Directorate of Renewable Energy, BEPA Graphs 2018 http://www.yegm.gov.tr/ (Accessed August 27, 2018).

[25] 24. Abdeshahian P., Lim J.S., Ho W.S., Hashim H., Lee C.T. Potential of biogas production from farm animal waste in Malaysia, Renewable and Sustainable Energy Reviews; 2016, 60: 714-723. http://dx.doi.org/10.1016/j.rser.2016.01.117

[26] 25. Benito M., Ortiz I., Rodríguez L., Muñoz G. Ni-Co bimetallic catalyst for hydrogen production in sewage treatment plants: biogas reforming and tars removal. Int J Hydrogen Energy 2015; 40:14456-68. https://doi.org/10.1016/j.ijhydene.2015.06.163

[27] 26. Possible agricultural use of digestate Kuusik A., Pachel K., Kuusik A., Loigu, E. Proceedings of the Estonian Academy of Sciences; 2017, 66: 64-74. https://doi.org/10.3176/proc.2017.1.10

[28] Macias-Corral, M., Samani, Z., Hanson, A., Smith, G., Funk, P., Yu, H., Longworth, J. Anaerobic digestion of municipal solid waste and agricultural waste and the effect of co-digestion with dairy cow manure. Bioresource Technology 2008; 99: 8288-8293. doi: 10.1016/j.biortech.2008.03.057

[29] Nzila, C., Njuguna, D., Madara, D., Githaiga, J., Muasya, R., Muumbo, A., Kiriamiti, H., Characterization of Agro-Residues for Biogas Production and Nutrient Recovery in Kenya. Journal of Emerging Trends in Engineering and Applied Sciences 2015;6: 327-334. ISSN: 2141-7016.

[30] Abo, B.O., Kalakodio, L., Bakayoko, M. Evaluation of the Biogas Production Potential by Anaerobic Digestion of Fermentable Agricultural Residues in Côte d'Ivoire. International Journal of Waste Resources 2017; 7: 1-6. DOI: 10.4172/2252-5211.1000317

[31] Lehtomäki, A., Huttunen, S., Rintala, J. Laboratory investigations on codigestion of energy crops and crop residues with cow manure for methane production: effect of crop to manure ratio. Resour. Conserv. Recycl. 2007; 51: 591-609. https://doi.org/10.1016/j.resconrec.2006.11.004

Tiquia S.M., Tam N.F.Y., Hodgkiss I.J. Effects of composting on phytotoxicity of spent pig-manure sawdust litter. Environmental Pollution 1996, 93: 249-256. https://doi.org/10.1016/S0269-7491(96)00052-8 